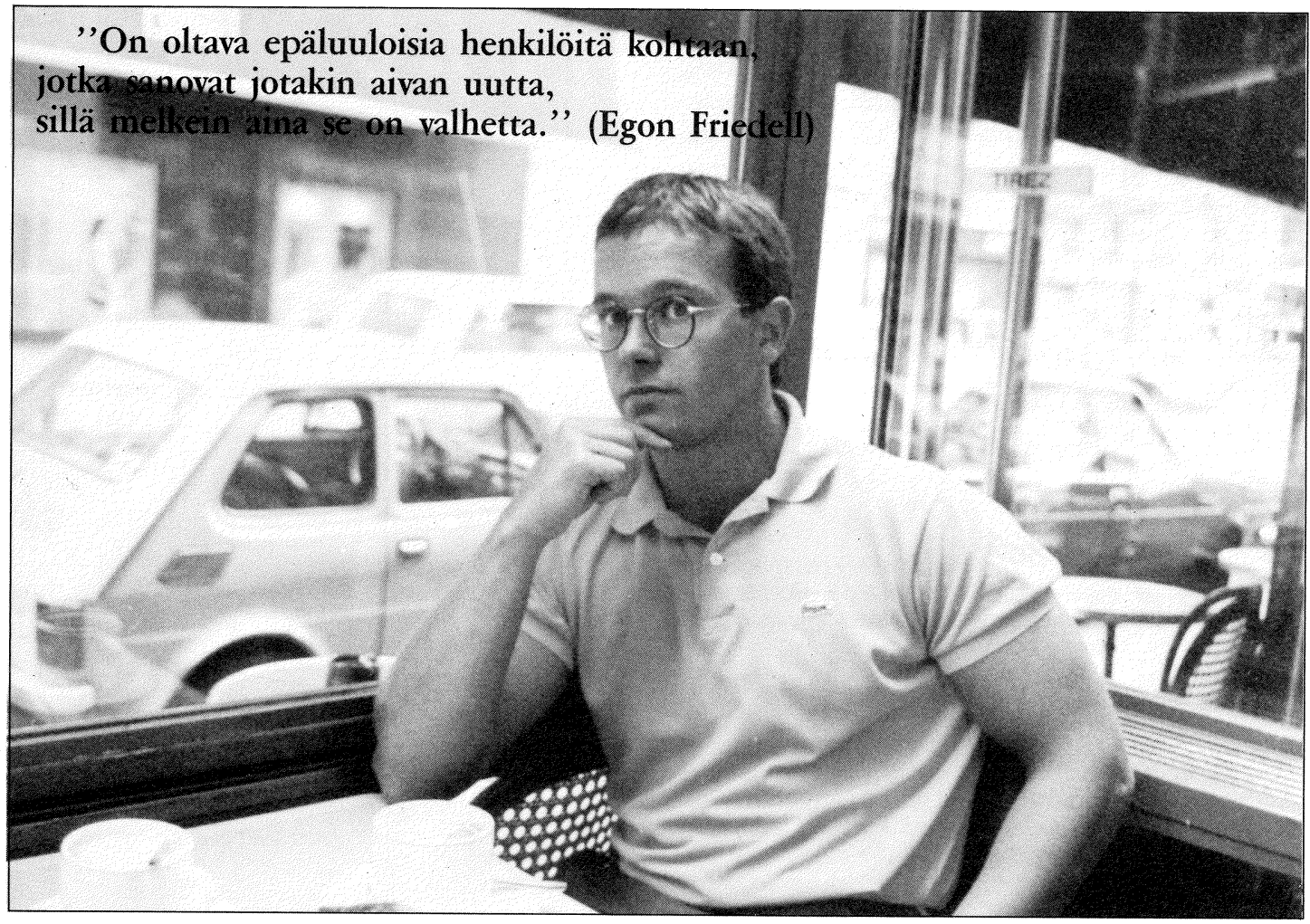

JUHA SUORANTA

\title{
Aikuiskasvatuksen ihmiskuvan poetiikkaa
}

\section{Todellisuudelle vieras ihmiskuva?}

Erään kommentaarin mukaan aikuiskasvatuksen ihmiskuvasta kirjoitetun muistion (Vaherva 1981) "keskeinen piirre" on "epähumanistisuus" ja sen "'aikaan ja paikkaan sitomaton, abstrakti tarkastelutapa". Toinen huomauttaa ihmiskuvatarkastelua "abstraktista yksilökeskeisestä otteesta". "'Silmiinpistävä piirre" on myös ihmiskuvan "ristiriidattomuus ja staattisuus". Muistion ihmiskuva on kaiken kaikkiaan "'todellisuudelle vieras". Yhtä paljon kuin muistio on vieras todellisuudelle, on se vieras myös tuonpuoleiselle, sillä se "'ei käsittele ... aikuisen uskonnollista kehitystä". Sitaatit ovat esimerkkejä sanakäänteistä, joita Tapio Vahervan muistio "'Aikuiskoulutuksen ihmiskuva" herätti. Alunperin aikuiskoulutuksen johtoryhmä halusi muistion lähtökohdaksi alan kehittämistyölle. Aikuiskasvatus- lehti viritti muistion pohjalta keskustelun aikuiskasvatuksen ihmiskuvasta. Tässä artikkelissa palaan lehdessä käytyyn keskusteluun. En kuitenkaan osallistu keskusteluun sen sisällöllisellä tasolla ottaen kantaa millaisia erilaisia ihmiskuvia/käsityksiä aikuiskasvatuksessa on tai pitäisi olla, vaan luen sitä diskursiivisesta näkökulmasta: miten aikuiskasvatuksen ihmiskuvista/käsityksistä keskustellaan? Vahervan muistion herättämän keskustelun jälkeen aikuiskasvatuksen ihmiskuvasta ei ole paljon puhuttu. Vuosikymmenen hiljaisuuden jälkeen ihmiskuvakeskustelu on yhä ajankohtainen. Kenties paluu keskusteluun uudesta näkökulmasta auttaa näkemään, mitä käyty keskustelu on merkinnyt aikuiskasvatuksen kehittämiselle - vai onko se merkinnyt mitään? Olisiko kenties niin, että ajoittainen puhe aikuiskasvatuksen arvofilosofiasta onkin rakentamassa harhaista todellisuutta, jossa ihmiskuvien/käsitysten uskotaan vai- 
kuttavan käytännön kehittämistyöhön vaikka näin ei todellisuudessa tapahdu? Tai vielä jyrkemmin: sanan ei edes uskota muuttuvan lihaksi, kyse on vain puheesta. Aiheen pohdinta korostuu nykyisessä tilanteessa - onhan suomalainen aikuiskasvatustoiminta keskustelun ajoista suuresti laajentunut. Aikuiskasvatus-lehti oli pyytänyt kolmea henkilöä arvioimaan ihmiskuvamuistiota. Arvioivat puheenvuorot julkaistiin vuoden 1982 ensimmäisessä numerossa. Aiemmin aihetta käsitteli lehden nimimerkki Andragogi ja myöhemmin keskusteluun vastasi yksi kirjoittaja. Aikuiskasvatuksen Tutkimusseuran vuoden 1982 vuosikokouksen jälkeen teemasta pidettiin myös keskustelutilaisuus.

Tarkastelen artikkelissani Vahervan muistiosta virinnyttä/viritettyä puhetta ihmiskuvasta/käsityksestä, en muistiota sinänsä, vaikka siihenkin tulen viittaamaan. Puheen moninaisuus ja erilaiset vaikutuskeinot juontavat siitä, että puhujat edustavat sangen erilaisia päämääriä, organisaatioita ja niin iällisiä kuin tieteellisiäkin aikakausia (ts. paradigmoja). Keskeisiä eivät ole keskustelijat vaan heidän puhetapansa.

\section{Diskursiivinen käänne}

Diskursiivinen näkökulma erilaisiin teksteihin ja käytäntöihin on alkanut viime vuosina saada sijaa sekä ihmis- että luonnontieteiden itseymmärryksessä. Ihmistieteissä suuntausta kutsutaan esimerkiksi retoriseksi lähestymistavaksi, sosiologian poetiikaksi tai diskurssianalyysiksi (DA, Suomessa lähestymistavasta on käytetty $\mathrm{mm}$. nimitystä kielen käytön tutkimus.) Ei vain arkipuhetta ja -toimintaa, vaan myös tiedettä on ryhdytty tarkastelemaan retorisena aktiviteettina (ks. esimerkiksi Gilbert \& Mulkay 1982). Vaikka em. suuntaukset ovat monivivahteisia, kaikkien taustalla on sosiaalisen konstruktivismin (Berger \& Luckmann 1984) ajatus. Sen mukaan kielen käytöllä rakennetaan tietoisesti tai tullaan huomaamatta rakentaneeksi sosiaalista todellisuutta. Puhe ja kirjoitus eivät ole tosiasiakuvauksia ilman tietoisia tai huomaamattomia arvostuksia. Tekstit ovat "puhetekoja" (Austin 1990), joilla pyritään vaikuttamaan ja vakuuttamaan. Tällöin on tärkeät kiinnittää huomiota pikemmin tekstien muotoihin - niihin puhetapoihin ja retorisiin strategioihin, joilla asioita esitetään - kuin tekstien sisältöön (Suoranta 1991).

Jako muotoon ja sisältöön on tosin ongelmallinen, sillä voidaanhan ajatella ensisijaisesti muodon tuottavan tekstiin merkityksi ja muotojen tarkastelun opettavan erilaisten tekstien lukutaitoa sekä syventävän niiden sisällön ymmärtämistä.

DA ei ole vakiintunut tutkimusmenetelmä, vaan lähestymistapa, joka sallii erilaisten menetelmien käytön tiettyyn tekstimassaan (Billig 1991, 22). Aineistojen diskursiiviseen lukutapaan ei ole tarjolla valmista kaavaa - vihjeitä keskustelun analyysiin löytyy esimerkiksi Potterilta \& Wetherelliltä (1987). Varsinaista empiirisen aineiston keräystä ei DA:ta varten välttämättä tarvita, sillä soveltuvaa materiaalia on muutoinkin ulottuvilla. Tosin esimerkiksi eläytymismenetelmä (ks. Eskola \& Suoranta 1991; Eskola 1991) tuottaa DA:iin soveltuvaa tekstiaineistoa varsin vaivattomasti.

Diskursiivinen lähestymistapa soveltuu hyvin jonkin selvärajaisen tekstiaineiston eli korpuksen tutkimukseen. Oma 15 sivun aineistoni on peräisin aikuiskasvatuslehden 1 . ja 2 . vuosikerrasta. Analysoitavat tekstit voivat olla sekä puhuttua että kirjoitettua materiaalia, yhtä hyvin keskusteluja, uutisia ja romaaneja kuin tieteellisiä tekstejäkin. Retorinen, poeettinen tai diskurssianalyyttinen tutkimus voivat viitata (1) lauserakenteiden lingvistiseen tutkimukseen, (2) tekstien sisällönerittelyyn, jossa tulkinnat perustuvat esimerkiksi tiettyjen sanojen esiintymistiheyteen, (3) foucaultlaiseen valtadiskurssien analyysiin tai (4) lähestymistapaan, jossa ei kysytä tekstin merkityksiä, vaan sitä miten merkityksiä tuotetaan teksteissä. Käsillä olevaa keskustelua analysoin jälkimmäisestä (4) näkökulmasta pitäen mielessä DA:n perusidean eritellä kielen käytön moninaisuutta ja niitä tapoja, joilla kieltä käytettäessä rakennetaan tai tullaan rakentaneeksi sosiaalista todellisuutta. Pelkistetyimmillään DA on tekstimateriaalien yhä uudelleen lukemista ja tulkintaa. Luin keskustelua mielessäni (ennakko-oletusteni lisäksi) seuraavanlaisia kysymyksiä:

Mitä keskustelun peruskäsitteillä tarkoitetaan tai halutaan tarkoittaa?

Millaisia kielikuvia keskustelusta löytyy?

$\square$ Ketkä tai mitkä ovat keskustelun auktoriteetteja?

$\square$ Lisäksi, olisiko keskustelusta löydettävissä juuri aikuiskasvatuksen kielelle (liturgialle) tyypillisiä sanakäänteitä, jotka voisin nimetä toisistaan erottuviksi puhetavoiksi?

Artikkelini jatkoluvut rakentuvat pääosin näistä kysymyksistä. 


\section{Ihmiskuva, -käsitys vai -katsomus?}

Keskeinen kysymys on tutkia, miten peruskäsitteet määritellään. Keskustelussa käsite-erotteluja ei juurikaan tehdä: ihmiskuvalla, -käsityksellä ja -katsomuksella tarkoitetaan enemmän tai vähemmän samaa. Siitäkin huolimatta, että kritiikin kohteessa, aikuiskoulutuksen ihmiskuvamuistiossa, ihmiskäsitys ja ihmiskuva määritellään todeten niiden käytön olleen "horjuvaa nimenomaan käsitteiden merkityssisällön osalta":

\begin{abstract}
'Ihmiskäsitys tarkoittaa uskomuksiin ja arvostuksiin perustuvaa, useimmiten oletusten tasolla olevaa käsitystä siitä, mikä ihminen on, mikä ibmisessä on olennaista ja mitkä ovat ibmisen mahdollisuudet. Ihmiskäsitys on metatasoinen konseptio sisältäen sellaisia aineksia, joibin empiirisen tutkimuksen avulla on hankala tai täysin mahdoton päästä käsiksi. Ihmiskäsitys on eräälainen esioletus, joka muodostaa perustan empiirisille tieteille näiden pyrkiessä mahdollisimman todelliseen ja todenmukaiseen kuvaan siitä, mitä ibminen on." (Vaherva 1981)
\end{abstract}

Peruskäsitteiden määrittelyt tekevät ymmärrettäväksi keskustelun käsiteyksimielisyyden. Kuka haluaisi puhua ihmiskäsityksestä, joka esitetään vähintäin hankalana tai täysin hämäränä käsitteenä. Ihmiskäsitys perustuu "uskomuksiin ja arvostuksiin" ja on "metatasoinen konseptio", kun taas

\footnotetext{
'Ihmiskuva tarkoittaa kokemusperäiselle tutkimukselle, ihmistieteiden tuottamalle tiedolle rakentuvaa kuvaa ihmisestä mahdollisuuksineen. Ihmiskuva voi olla sekä deskriptiivinen eli kuvaileva tai normatiivinen eli ihanteellinen. Deskriptiivinen ihmiskuva ilmaisee näkemyksen (toivottavasti tutkimustietoon pohjautuen) ihmisen kyvyistä, elämäntilanteista, kehittymisen ja kasvatuksen mahdollisuuksista. Normativinen ihmiskuva puolestaan ilmaisee ibmisihanteen, ts. kasvatuksen päämääräksi asetettavan ihanteellisen ihmiskuvan." (Vaherva 1981)
}

Ensilukemisella tekstikatkelmat vaikuttavat kuvailevilta. Tämä on tosin näennäistä, sillä katkelmissa piilee eräänlainen painotettu vertailu. Riveiltä voi lukea, kuinka niissä kuin salavihkaa tuodaan ilmi mm. se, että ihmiskäsitys on "oletusten tasolla" ja ihmiskuva rakentuu "kokemusperäiselle tutkimukselle". Ihmiskuva perustuu "ihmistieteiden tuottamalle tiedolle", kun taas ihmiskäsitys on "eräänlainen esioletus". Ihmiskuvan käsitettä, joka perustuu "toivottavasti tutkimustietoon" on huomattavasti turvallisempi käyttää kuin hämärää ihmiskäsitystä: voihan ihmiskuva olla sekä "deskriptiivinen eli kuvaileva tai normatiivinen eli ibanteellinen".

Keskustelusta löytyy yksi ehdotus käsitteiden uusjaolle. Sen mukaan ihmiskuva ja -käsitys olisivat samaa tarkoittavia ja erottavana käsitteenä toimisi "ihmiskatsomus, joka vastaa kysymykseen, minkälainen ihmisen pitää olla." Ihmiskatsomuksen maanläheinen tulkinta tekee ehdotuksen mielenkiintoiseksi :

"Mutkattominta on kuitenkin sanoa, ett aikuiskasvatuksen suunnittelun pitää läbteä niiden ibmiskatsomusten tunnustamisesta, jotka aikuiskasvatuksessamme ovat olemassa (kristillinen, marxilainen, humanistinen, työväenluokan ja maanviljelijäväestön).",

\section{Uinuvat metaforat}

Uinuvilla metaforilla tarkoitetaan sellaisia kielikuvia jotka ikäänkuin hiipivät kielen käyttöön siten, että niiden kuvaluonnetta on enää vaikeata tunnistaa (Summa 1989, 166). Kielikuvat eivät kuulu ainoastaan kaunokirjallisuuteen vaan ovat osa myös tieteellistyyppisiä tekstejä (ks. esim. Atkinson 1990, 50-53). Kriittisyyteen pyrkivissä kommenttipuheenvuoroissa metaforat ovat sekä näkyvämpiä että näkymättömämpiä. Poliittis-hallinnollisesta ja luonnontieteellisestä kielestä metaforiksi ihmiskuvakeskusteluun ovat tarttuneet $\mathrm{mm}$. voimasuhteet, pitkäjänteiset toimintalinjat, prosessi, dynamiikka ja tehokkuus:

\footnotetext{
"Opetuksen on osoitettava opiskelijoille mahdollisimman tehokas tapa hankkia ne tiedot ja taidot... ."
}

Keskustelun näkyvämmissä metaforissa esimerkiksi 'seisotaan humanistis-demokraattisen kulttuuripluralismin pobjalla" ja "piirretään humanistinen ihmiskatsomus avaraksi". Materialistisessa ihmiskatsomuksessa "vaanii vaara", että humanistinen ihmiskäsitys "'bämärtyy". Puhutaan "näköalattomasta" tai "pysähtyneestä" ihmiskuvasta ja siitä kuinka ihmisarvon "korostus kutistuu'. Voi vain ihmetellä, miten ihmiskatsomusta piirretään?:

\footnotetext{
"Aikuiskasvatuksen perustaksi humanistinen ihmiskatsomus saattaa riittää, jos se piirretään niin avaraksi, että.. .'
}

Edelliset metaforat jäävät, syvästikin tulkitsemalla, kovin hämäriksi. Metaforien käyttö on monellakin tavalla ongelmallista. Ensinnäkin niihin saatetaan turvautua tunneperäisesti, kun halu- 
taan sanoa jostakin asiasta jotakin painavaa, mutta argumenteille ei löydykään enemmälti perusteltuja. Toiseksi voi olla kysymys tavasta tai tottumuksesta kuitata perustelu enemmän tai vähemmän tietoisella metaforan käytöllä. Tietoisesti ja taitavasti käytettynä metafora vahvistaa sanottavaa ja konnotoi sivumerkityksiä ja mielleyhtymiä. Metaforien problematisoimaton käyttö taas laskee argumentoinnin uskottavuutta ja johtaa ojasta allikkoon. Ko. keskustelussa metaforat kertoivat retorisina jälkinä vain harvoin, jos ollenkaan, taitavista käyttäjistään:

\footnotetext{
"'Mutta ensiluokkaisen tärkeä on kysymys, miten tiedon valtamerestä ja tiedon tulvasta saataisiin aikuiskasvattajien käyttöön juuri sellaista tietoa, jota he tarvitsevat."
}

\section{Puhetavat ja auktoriteetit}

Eräs tapa pyrkiä lisäämään tekstin vaikuttavuutta on vedota tunnustettuihin iskulauseisiin ja/tai auktoriteetteihin. Hyviä keinoja on tietysti useita (ks. esim. Luostarinen \& Väliverronen 1991, 96-97 \& 101-102), mutta ihmiskäsityskeskustelun silmiinpistävimpiä ovat 'bumanismin aate ja humanistinen ihmiskuva." Humanismiin ei pure ruoste eikä koi: "Vaikka humanismin aate on aikojen kuluessa vaibdellut, niin se on kuitenkin säilynyt elinvoimaisena." Keskustelusta on erotettavissa ainakin kaksi erilaista puhetapaa humanismista. Puhetavoista on mahdollista erotella auktoriteettiin vetoamisten, kysymystenasettelujen ja julkilausumattomuuksien eri strategioita.

Dogmaattisessa puhetavassa korostetaan esimerkiksi humanismin kaikkivoipaisuutta. Vaikka on olemassa lukuisia erilaisia ihmiskuvia, niin "tietyllä yleisyystasolla" yksimielisyys oikeasta ihmiskuvasta löytyy. Humanismi löytyy suomalaisesta kasvatusperinteestä. Dogmaattisessa puhetavassa kysymykset asetetaan niin, ettei kunnon humanisti voi sanoa muuta kuin ei:

\section{'Onko meillä varaa irrottautua suomalaisen kasvatusajattelun parbaista perinteistä?" 'Tarvi- taanko suomalaisen aikuiskoulutuksen suunnitte- lun pohjaksi todella ibmiskuvaa, joka ei näe ib- mistä historiallisesti kehittyvän kulttuuriolentona, joka juuri sivistystä omaksumalla ja luomalla luo myös oman ihmisyytensä?",}

Ja jos jotkin muut katsomukset uhkaavat aatetta "'bumanisti taistelee niitä vastaan aseena se ainoa ase, jonka humanisti Erasmus Rotterdamilaisen mukaan voi hyväksyä, nimittäin sermo, pube, ei esimerkiksi tukahduttavat kasvatuspoliittiset toimen- piteet." On nimittäin olemassa "ideologioita, joiden ylläpitäjät koettavat istuttaa toisten ibmisten mieleen väärän kuvan ibmisestä."

Vastakohtana dogmaattiselle puhetavalle liberaaleissa sanakäänteissä hyväksytään erilaisia ihmiskuvia, -käsityksiä ja -katsomuksia. Liberaalissa puhetavassa aikuiskoulutuksen kehittämisen lähtökohdaksi löydetään vuoden 1971 komiteamietinnöstä humanismi ja epäillään, "'ettei aikuiskasvatuksen kehittämisen lähtökohdaksi ole nytkään löydettävissä parempaa ihmiskuvaa." Siinä vastustetaan yhden ihmiskäsityksen kasvatusjärjestelmiä ja nähdään myös suomalaisessa kasvatusjärjestelmässä 'totalitaarisia pyrkimyksiä ja piirteitä." 'Liberaali puhetapa on siinä mielessä ristiriitainen, että sekin sallii yhden ihmiskatsomuksen ylitse muiden:

'Jos ainoaksi ihmiskatsomukseksi asetetaan bumanistinen ihmiskäsitys, tavallaan hyväksyn sen, koska tämä on liberaalinen katsomus, joka ei kiellä olemassaolon oikeutusta muilta katsomuksilta."

Liberaalissa puhetavassa kysymykset asetetaan miedon vihjaaviksi - 'Ihmiskuvastako uusi kehittämisen lähtökohta?" - ja pehmennetään sanottavaa: "'luulen ettei".., "saattaa tietysti olla".. ja "'epäilen, ettei"...

Keskustelun kolmas puhetapa pyrkii eroon ilmassa leijuvasta humanismin korostuksesta. Humanistiset yleiset pohdinnat herättävät jopa pienen pelon, "että ihmiskuvapohdiskelut irtautuvat käytännön todellisuudesta. Tällöin belposti syntyy rakenne, joka muistuttaa sitä, mitä korkeakoulututkimuksessa on kutsuttu piilossa olevaksi opetussuunnitelmaksi.."

Jo mainittujen humanismin aatteen ja Erasmus Rotterdamilaisen lisäksi keskustelusta löytyy muitakin auktoriteetteja. Tunnustettujen henkilöiden sitaatit toimivat keskustelun toteemeina. Sitaatit sitovat yhteen kirjoittajan ja siteeratun. Sitaatit eivät ainoastaan viittaa vaan myös vihjaavat mihin leiriin kirjoittaja kuuluu (Atkinson 1990, 44). Uudella kirjoittajalla on oikein siteeraten mahdollisuus päästä itse mukaan "sitaattikaruselliin" (Luostarinen \& Väliverronen 1991, 96). Eräs tapa nostaa puheenvuoron arvonantoa on aloittaa Antiikista, mainita muutama edesmennyt suuruus tai vielä vaikuttava alan tunnustettu nimi. Voi vaikkapa kertoa, että "meidän länsimainen sivistyksemme pobjautuu pitkälti kreikkalaisten filosofien laskemalle perustalle"... "josta on suunnattomasti tietoa yli kahden vuositubannen varrelta..'

Tunnustetuista nimistä keskustelussa käy varsin sekalainen seurakunta: "Piispa Eino Sormunen mainitsi".., "viittaan vain Oiva Ketosen sanoihin:".., itseoikeutettuina "'G. H. von Wright aset- 
taa humanismille kaksi keskeistä määrettä:'.. ja "Matti Peltonen käsittelee koulunuudistuksen ihmiskäsitystä'..., 'Kuitenkin jo Eino Kaila tähdensi,.. "'siteeraisin Eric Frommia:"..., "Snellman esitti aikanaan mahtavan näkemyksen ibmisestä sivistyksen avulla rajoittuneen yksilöllisen lähtökohtansa ylittävänä, kehittyvänä ibmiskunnan jäsenenä." ja lopulta "eksistenssifilosofian mukaan ihmisen oleminen on olemista kuolemaan, Sein zum Tode (Heidegger)".

Keskustelu sisältää em. julkisten auktoriteettien lisäksi joukon piiloisempia auktoriteetteja. Omaa kantaansa voi perustella joko määrällisiin tai laadullisiin julkilausumattomuuksiin vetoamalla (Perelman \& Olbrechts-Tyteca 1971). Kvantitatiivisessa perustelussa vedotaan jonkin asiantilan paremmuuteen viittaamalla suurempaan määrään: demokratiaan, yleiseen mielipiteeseen, tutkimusaineiston tai otoksen suuruuteen tai "meibin humanisteihin". Kvalitatiivinen perustelu koskettaa asiantilan ainutkertaisuutta ja vetoaa kykyyn kyseenalaistaa vallitseva käsitys. Näin keskustelussa toimivat "nuoruutensa sodassa viettänyt, pientilansa sodan jälkeen myynyt ja nyt kaupungissa asustava työllisyyskurssille objattu kirvesmies" tai "teollisuuskonsernin omistajan poika Kulosaaresta".

\section{Moniäänisyyden paradoksi}

Konstruktivistinen asenne saattaa johtaa tiedon ja totuuden relativoimiseen. Niiniluoto (1990, 67-68) esittää relativismille tyypillisen ongelman: kielen käytön tutkija olettaa työssään, että teksteillä on sosiaaliset syntykontekstit, mutta jättää vastaamatta koskeeko oletus myös tutkijan omaa työtä - vaikkapa käsillä olevan keskustelun analyysia. Se, että retoriikkaa voi samalla sekä tutkia erilaisissa teksteissä että käyttää argumentointinsa välineenä mahdollistaa kriittisen asenteen tekstejä kohtaan (Billig 1991, 23). Kielen käytön tutkijana minun on tiedostettava, että myös itse turvaudun samoihin retorisiin strategioihin, joita juuri analysoin - myös tätä artikkelia voi (ja kannattaa) lukea diskursiivisesti.

DA:ssa joutuu jatkuvasti kyseenalaistamaan omia kielen käytön tapojaan. Menetelmän hedelmällisyys on siinä, että se asettaa kielen käytön uuteen asemaan yhteiskunta- ja kasvatustieteellisessä tutkimuksessa. Esitettyihin perusteluihin voi esittää aina vastaperustelun. Moniäänisessä kriittisessä keskustelussa jokaisella puhujalla on vastuu sanoilla rakennetusta todellisuudesta. Moniäänisyydessäkin on tosin paradoksinsa: toiset ovat moniäänisempiä kuin toiset.
Artikkelia lukiessa on välillä saattanut ihmetyttää, enkö osaa päättää kumpaa käsitettä käyttäisin: ihmiskuvaa vai ihmiskäsitystä. Kauttaviivalla kuvaan kuitenkin sitä, että jomman kumman käsitteen käyttö on jo sinänsä valinta. 'Ihmiskuvan'" käyttöön johdattavat aikuiskoulutuksen kehittämisen yleissuunnitelma ja toiseksi Vahervan muistio. Yleissuunnitelmassa puhutaan "aikuiskoulutuksen ihmiskuvasta" ja keskustelua käydään hanakasti Vahervan saaman toimeksiannon mukaisesti "deskriptiivisestä ihmiskuvasta". Ihmiskuvan käsitteen ottaminen annettuna on pohdinnan arvoinen valinta. Filosofisessa diskurssissa ihmiskuvan ja -käsityksen käsite-erosta on keskusteltu paljonkin. Eräässä filosofisen antropologian näkemyksessä ihmiskuva varataan erityistieteiden osittaiskuvauksille ihmisestä ja ihmiskäsitys filosofiselle antropologialle itselleen sekä ontologisille peruskysymyksille ihmisestä kokonaisuutena (ks. Rauhala 1983).

Sosiaalisella tekstillä on aina myös kontekstinsa. Sen lisäksi perustelut ovat aina sopimuksenvaraisia. Ihmiskuvakeskustelu käytiin tieteellisen aikakauslehden keskustelua-sivuilla: Keskustelupuheenvuoron säännöt ja vaikuttamiskeinot eroavat esimerkiksi artikkeli- tai uutistyyppisen kirjoituksen puhetavoista. On eri asia kirjoittaa uutismainen katsaus Färsaarten aikuiskoulutuksesta tai Kirgisiassa pidetystä lukutaidottomuus-seminaarista kuin vakuuttava puheenvuoro ihmiskuvakeskusteluun. Puhe ihmiskuvasta on varsin abstraktia. Osallistuminen tämän kaltaiseen keskusteluun vaatii vaikeaselkoisen erikoiskielen tai filosofisen munkkilatinan hallintaa. Keino välttää osallistuminen on pelata omaa sanapeliä ja ottaa asiaan uuden, "avartavan" näkökulman:

\footnotetext{
'Kenties on avartavaakin aikuiskasvattajien lehdessä katsoa, miten jonkin lähitieteen ... edustaja joutuu miettimään ibmiskuvaan liittyviä ongelmia omassa työssään'..'
}

Koko keskustelun lähtökohtaa, aikuiskoulutuksen kehittämisorganisaation tehtävänasettelua kannattaa ajatella osana aikuiskoulutustoiminnan oikeuttamista ja näin osana aikuiskasvatuksen poetiikkaa. Ihmiskuva tai -käsitys ymmärretään analysoidussa keskustelussa hyvin yleisen konstruktiona jonka avulla voidaan kuvata ja pyrkiä hallitsemaan kasvatukseksi nimitettyyn alaan kuuluvia toisia konstruktioita eli todellisten tai kuviteltujen ilmiöiden käsitteellisiä yleistyksiä. Samaan aikuiskasvatuksen poetiikkaan kuuluu myös huomautus ihmiskuvamuodista: 


\begin{abstract}
'Ihmiskuva on nyt siis aikuiskasvatuksessa 'in'. Vaikka tämäntapaiseen muoti-ilmiöön onkin syytä subtautua aina varovaisesti, niin sitä ei voida jättää buomiotta, varsinkin kun aikuiskoulutuksen kehittämisorganisaatio on antanut sille niin keskeisen aseman omassa työssään.",
\end{abstract}

Vaikka aikuiskoulutuksen kehittämisorganisaatio korostaa ihmiskuvan keskeisyyttä kehittämistyön perustana selvää kai on, että ihmiskuvakeskustelu on "muoti" siinä mielessä ettei sillä paljonkaan ole ohjailtu eikä ohjailla aikuiskoulutuksen kehittämistä. Optimistisempiakin arvioita on esitetty. Sandelin $(1983,75)$ huomauttaa, että käydystä sisällöllisestä keskustelusta huolimatta ainakin ihmiskuvan käsite sinänsä vakiintui aikuiskasvatuksen alueelle vaikuttaen tavalla tai toisella aikuiskasvatuksen käytäntöihin. Mielenkiintoista olisi laajentaa diskursiivista tarkastelua esim. aikuiskoulutuksen hallintokieleen: miten sen raskas ja monipolvinen käsiteapparaatti ja kielitodellisuus eroaa ihmiskuvakeskustelun retoriikasta?

Dogmaattinen ja liberaalinen puhetapa humanismista ovat keskeinen osa aikuiskasvatuksen jargonia, aikuiskasvatuksen ihmiskuvan poetiikkaa. Humanismi toimii keskustelussa Valistusajan kuvitteellisten matkakertomusten, YK:n ihmisoikeuksien julistuksen, puolueiden vaaliohjelmien tai koulutuspoliittisten komiteamietintöjen ja ohjelmanjulistusten tapaan. Se on keskustelun iskulause, jolla lisätään sanottavan painavuutta. Humanismin voi sanoa olevan science fictionien tapainen kuvitteellinen kertomus, joka täyttää periaatteellisen toteutumisen mahdollisuuden, mutta ei silti koskaan toteudu.

\section{Diskursiivisesta lukutavasta opinnolliseen}

Analysoimani keskustelu on pieni osa kaikista mahdollisista aikuiskasvatuksen alueelle laskettavista teksteistä. Keskittymällä pelkkiin teksteihin hukataan helposti käytännön elämä ja sen asettamat haasteet - kaikki kasvatus ei tietenkään ole pelkkää diskurssia. On kuitenkin huomionarvoista, että merkittävää osaa kasvatustoiminnasta - puhumattakaan kasvatusalan todellisista teksteistä - voi lukea diskursiivisesti. Lähestymistapaa on mahdollista soveltaa myös muihin eteen tuleviin teksteihin. Kiintoisaa olisi kohdistaa DA esimerkiksi kasvatusalan mietintöihin, lakeihin ja säädöksiin, erilaisiin opetus- ja oppimateriaaleihin, didaktisiin malleihin ja usein itsestään selvyyksinä pidettyihin teoriakehitelmiin sekä luokkahuone- tai opetustilannepuhee- seen. Opetustilannepuheen analyysi saattaa antaa lisävalaistusta aikuiskasvatuksen piiloisiin käytäntöihin (vrt. Florio-Ruane 1987, 189).

Olen analysoinut erästä aikuiskasvatuksen alueella käytyä keskustelua diskurssianalyysin antamin vinkein. Analyysini kenties keskeisin opetus on se, ettei aina ole välttämätöntä uskoa, yhtyä tai esittää eriäviä näkemyksiä esitettyihin näkökantoihin vaan on mahdollista keskittyä näkemysten rakentumiseen teksteissä. Diskursiivinen näkökulma onkin hedelmällistä kääntää opinnolliseksi lukemalla mitä vaihtelevampia tekstikatkelmia ikäänkuin sivullinen ja kysyä miten teksti pyrkii vaikuttamaan tai millaista todellisuutta teksti synnyttää. Käsillä oleva ihmiskuva/käsityskeskustelu on kapea osa koulutuspolitiikkaa ja siten osa yhteiskunnan yleistä poliittista diskurssia. Koulutuspoliittisilla diskursseilla, joilla tarkoitan koulutusta koskevaa päätöksentekoa ja lainsäädäntöä, on viimekädessä vaikutuksia aikuiskasvatuksen käytännön kenttään. Aikuiskasvatuksessa herätetty ihmiskuvakeskustelu onkin nähtävä osana laajempaa koulutuspoliittista debattia. Tältä pohjalta en malta olla ottamatta lopuksi esille vielä yhtä kysymystä ihmiskuva/käsityskeskustelusta. Kun keskustelu ihmiskuvasta aikanaan aloitettiin aikuiskasvatuksen suunnittelun lähtökohtana, kuulosti aihe kovin uudelta. Aiemmin aikuiskasvatuksen filosofisemmat kysymykset olivat olleet perin $\mathrm{H}$ /harvassa. Mistä sitten johtui äkkinäinen kiinnostus filosofisen antropologian peruskysymykseen mikä on ihminen? ja erityisesti mikä ihminen on aikuiskasvatuksen näkökulmasta? Kyseessä saattaa olla historian tavanomainen aaltoliike: tänään puhutaan ihmiskuvasta, huomenna jostain muusta. Tähän viittaisi ajatus, jonka mukaan välillä erityistieteissä havahdutaan filosofiseen pohdiskeluun ja oman tieteenalan perustojen etsintään kun taas toisinaan suunta on pois filosofiasta ja joutavasta metafysiikasta (mukaan lukien ihmiskuva/käsityskysymykset).

Diskursiivinen lähestymistapa on varsin uudenlainen tapa lukea erilaisia tekstejä. Se saattaa auttaa näkemään tekstissä piilevän merkityksen siinä, missä sitä ei ensin ollut. DA ei mahdollista ainoastaan ihmiskuva/käsityskeskustelun tapaisten tekstien analysointia. Miettimisen aihetta tarjoaa koko se aikuiskasvatuksen käsitekoneisto, jota tällä hetkellä tarvitaan alan pyörittämiseen. Mieleen nousee uudelleen alussa esittämäni kysymys hieman muutettuna: mitä aikuiskoulutuksen suunnaton korostaminen lopulta merkitsee? Onko se merkki yksittäiset toimijat ja intressipiirit ylittävästä tarkoittamattomasta yhteisvaikutuksesta koulutusta koskevassa päätöksenteossa? Tarkoittamattomalla yhteisvaikutuksella osoitan konsensusta, yhteiskuntasopimusta 
tms. yhteiskunnallisesta keskustelusta tuttuja sananparsia, jotka leimaavat myös koulutuspoliittisia liturgioita. Edellisen kaltaisilla iskusanoilla meidät vakuutetaan yhteishyvän nimissä $\mathrm{mm}$. koulutusta koskevan päätöksenteon rationaalisuudesta. Dis- kurssianalyysin tapaisella tutkimusotteella on mahdollista pureutua aikuiskasvatukseksi nimitettyjen käytäntöjen kaikille tasoille - minkä sanominen on tietenkin vain osa esitykseni poetiikkaa ja yksi keino oikeuttaa tämä teksti.

\section{LÄHTEET}

\section{Keskusteluun osallistuivat:}

Ahonen, T-M. 1982. Vastine Antti Eskolan artikkeliin. Aikuiskasvatus 2 (2).

Andragogi 1981. Ihmiskuvastako uusi kehittämisen lähtökohta? Aikuiskasvatus 1(1).

Eskola, A. 1982. Välittömyyden myytti ja inmiskuva. Aikuiskasvatus 2 (1).

Harva, U. 1982. Inmiskäsitys, inmiskatsomus ja kasvatus. Aikuiskasvatus 2 (1).

Tuomisto, J. 1982. Aikuiskoulutuksen inmiskuva - kehittämisorganisaation keskustelunavaus. Aikuiskasvatus 2 (1).

Virkkunen, J. 1982. Todellisuudelle vieras, näköalaton inmiskuva valtiolliseen käyttöön. Aikuiskasvatus 2 (1).

\section{Muut lähteet:}

Atkinson, P. 1990. The Ethnographic Imagination: Textual Construction of Reality. London: Routledge.

Austin, J. L. 1990. How to Do Things with Words. Oxford University Press. (1962)

Berger, P. \& Luckmann, T. 1984. The Social Construction of Reality. Pelican Books. (1966)

Billig, M. 1991. Ideology and Opinions: Studies in Rhetorical Psychology. London: SAGE.

Eskola, J. 1991. Eläytymismenetelmän käyttö sosiaalitutkimuksessa. Tampereen yliopiston sosiologian ja sosiaalipsykologian laitoksen työraportteja B: 33.
Eskola, J. \& Suoranta, J. 1991. Eläytymismenetelmä ja aikuiskasvatus - eläytyvää aikuiskasvatusta. Aikuiskasvatus nro 1.

Florio-Ruane, S. 1987. Sociolinguistics for Educational Researchers. American Educational Research Journal 2.

Gilbert, G. N. \& Mulkay, M. 1982. Joking Apart: Some Recommendations Concerning the Analysis of Scientific Culture. Social Studies of Science, 12.

Perelman, C. \& Olbrechts-Tyteca, L. 1971. The New Rhetoric. University of Notre Dame Press.

Potter, J. \& Wetherell, M. 1987. Discourse and Social Psychology. London: SAGE.

Luostarinen, H. \& Väliverronen, E. 1991. Tekstinsyöjät - yhteiskuntatieteellisen kirjallisuuden lukutaidosta. Jyväskylä: Vastapaino.

Niiniluoto, I. 1990. Maailma, minä ja kulttuuri. Keuruu: Otava.

Rauhala, L. 1983. Inmiskäsitys inmistyössä. Helsinki: Yliopistopaino.

Suoranta, J. 1991. Piileekö kasvatus kielessä? - diskurssianalyysista kasvatustieteellisenä lähestymistapana. Aikakauskirja Kasvatus 22 (5-6).

Summa, H. 1989. Hallinnon retoriikka ja politiikkojen synty. Politiikka nro 3 .

Sandelin, S. 1983. Suunnittelu, tulevaisuuden kuvat ja suunnittelevien ryhmien elämäntapa. Aikuiskasvatus 3 (2).

Vaherva, T. 1981. Aikuiskoulutuksen inmiskuva. Helsinki: Aikuiskoulutuksen johtoryhmä. 